\title{
PERENCANAAN COVERAGE JARINGAN 5G BERDASARKAN PROPAGASI RUGI RUGI LINTASAN DAN SHADOWING
}

\author{
Made Niama Dwi Susila ${ }^{1}$, Linawati ${ }^{2}$, Nyoman Gunantara*3 \\ 1,2,3Fakultas Teknik, Universitas Udayana \\ Email: ${ }^{1}$ madeniama@gmail.com, ${ }^{2}$ linawati@unud.ac.id, ${ }^{3}$ gunantara@unud.ac.id \\ *Penulis Korespondensi
}

(Naskah masuk: 10 Desember 2020, diterima untuk diterbitkan: 18 Maret 2021)

\begin{abstract}
Abstrak
Permintaan dan kebutuhan terhadap layanan jaringan yang lebih cendrung ke arah layanan data yang cepat dan bergerak, maka mendorong diperlukannya penerapan teknologi 5G. Teknologi 5G belum diimplementasikan di Indonesia. Sehingga pada penelitian ini dilakukan perencanaan jaringan $5 \mathrm{G}$ menggunakan sistem $5 \mathrm{G}$ dengan frekuensi $869 \mathrm{MHz}$ di Kota Denpasar memanfaatkan menara rooftop. Menara rooftop digunakan untuk menghemat ruang, lahan yang sifatnya terbatas, dan nilai estetika. Untuk itu lokasi menara ditempatkan pada bangunan yang bernama balai banjar. Ketinggian menara menyesuaikan dengan jumlah lantai dari balai banjar. Apabila balai banjar memiliki 1, 2, dan 3 lantai maka ketinggian menara juga menyesuaikan. Ketinggian menara secara berturut-turut adalah 13, 18 dan 22 meter. Pada perencanaan coverage menggunakan model propagasi rugi-rugi lintasan dengan pengaruh shadowing. Model propagasi ini digunakan dengan pertimbangan penggunaan frekuensi yang fleksibel dan kota Denpasar merupakan daerah urban. Tujuan dari penelitian ini adalah untuk mengetahui pemetaan lokasi menara rooftop dan coverage jaringan 5G di Kota Denpasar. Sehingga hasilnya dapat dijadikan pertimbangan dalam perencanaan jaringan 5G yang menggunakan menara rooftop. Perencanaan jaringan $5 \mathrm{G}$ dilakukan melalui menghitung jari-jari sel dengan model propagasi rugi-rugi lintasan dengan pengaruh shadowing, menghitung coverage, menghitung jumlah lokasi menara rooftop, dan pemetaan pada google earth. Hasil analisis adalah jari-jari yang dihasilkan adalah 70,4479 m dengan luas coverage $0,0129 \mathrm{~km}^{2}$. Jumlah menara rooftop yang diperlukan adalah 366 ditempatkan di balai banjar dan 11.550 ditempatkan di luar balai banjar. Sehingga pemanfaatan lokasi balai banjar sebagai lahan lokasi menara rooftop adalah sebesar 3,07\% dan di luar balai banjar sebesar $96,93 \%$
\end{abstract}

Kata kunci: rooftop, balai banjar, 5G, rugi-rugi lintasan, shadowing, coverage

\section{COVERAGE PLANNING ON THE 5G NETWORK BASED ON PATH LOSS PROPAGATION AND SHADOWING}

\begin{abstract}
The demand for and the need for network services that are more inclined towards fast and mobile data services, encourages the need for the application of 5G technology. 5G technology has not been implemented in Indonesia. So that in this study, a $5 G$ network planning was carried out using a $5 G$ system with a frequency of $869 \mathrm{MHz}$ in Denpasar City using a rooftop tower. Rooftop towers are used to save space, limited land, and aesthetic value. For this reason, the location of the tower is placed in a building called the balai banjar. The height of the tower adjusts to the number of floors of the balai banjar. If the balai banjar has 1, 2, and 3 floors, the tower height will also adjust. The tower heights are 13, 18 and 22 meters, respectively. In coverage planning using the path loss propagation model with shadowing effect. This propagation model is used considering the use of flexible frequencies and the city of Denpasar is an urban area. The purpose of this study is to determine the mapping of the rooftop tower location and $5 G$ network coverage in Denpasar City. So that the results can be taken into consideration in planning a $5 G$ network that uses a rooftop tower. Planning for the $5 G$ network is done by calculating the cell radius with the path loss propagation model with the shadowing effect, calculating coverage, calculating the number of rooftop tower locations, and mapping on Google Earth. The result of the analysis is that the resulting radius is $70.4479 \mathrm{~m}$ with a coverage area of $0.0129 \mathrm{~km}^{2}$. The required number of rooftop towers is 366 placed in the balai banjar and 11,550 placed outside the balai banjar. So that the use of the balai banjar location as a rooftop tower location is 3.07\% and outside the balai banjar is $96.93 \%$.
\end{abstract}

Keywords: rooftop, balai banjar, 5G, path loss, shadowing, coverage 


\section{PENDAHULUAN}

Kota Denpasar merupakan salah satu kota berkembang yang terdapat di Indonesia dalam bidang sektor pariwisata dan ekonomi. Meningkatnya kegiatan ekonomi dan pariwisata menyebabkan jumlah pertumbuhan dan kedatangan penduduk meningkat setiap tahunnya. Seiring dengan pertambahan jumlah penduduk dan perkembangan kegiatan, maka permintaan akan layanan data untuk keperluan telekomunikasi meningkat, sehingga semakin meningkat pula permintaan akan lahan yang digunakan sebagai penempatan menara telekomunikasi di atas tanah (green field). Namun kenyataannya lahan yang tersedia sangatlah terbatas. Di sisi lain dampak dari pembangunan menara yang terus meningkat akan berpotensi memperburuk estetika dan tata ruang kota.

Seiring perkembangan akan kebutuhan layanan data bergerak serta tingginya laju data di Kota Denpasar, maka diperlukan sebuah peningkatan kualitas jaringan informasi dan komunikasi yang dapat melayani seluruh kebutuhan pelanggan secara kuantitas maupun kualitas, salah satunya dengan tersedianya layanan jaringan $5 \mathrm{G}$. Kebutuhan yang tinggi dan ruang dan lahan yang sifatnya terbatas ini memicu berkembangnya menara rooftop yang memiliki micro coverage, dimana ketinggian antena tidak lebih dari 22 meter di kawasan perkotaan. Salah satu tempat yang sesuai untuk penempatan menara rooftop adalah di atas bangunan yang diberi nama balai banjar. Balai banjar merupakan sarana umum yang strategis untuk ditempatkan menara, khususnya di pulau Bali karena letak balai banjar tersebar di beberapa titik lokasi sekitar pemukinan warga. Balai banjar sendiri merupakan "wadah" bagi komunitas masyarakat Bali untuk melakukan kegiatan, dimana secara langsung hukum dan peraturan balai banjar telah di atur oleh pemerintah. Maka dari itu, selain biaya sewa akan jatuh ke tangan komunitas, pembangunan menara rooftop diatas bangunan balai banjar juga berguna untuk memudahkan pengaturan dan aspek perijinan. Dalam penerapannya dibutuhkan kajian terhadap coverage 5G pada penempatan rooftop balai banjar. Dalam perkiraan coverage menara dibutuhkan pemilihan model propagasi yang tepat. Model propagasi ditentukan berdasarkan objek penelitian dan spesifikasi menara rooftop. Beberapa Model propagasi outdoor untuk daerah urban telah banyak diteliti.

Menurut penelitian berjudul " $5 G$ Capacity Design Based on User Demand in Single High Altitude Platform Network [Desain Kapasitas Seluler 5G Berdasarkan Permintaan Pengguna pada Jaringan High Altitude Platform Tunggal]" oleh Iskandar memaparkan tentang HAPS (High Altitude Platform Station) sebagai alternatif teknologi telekomunikasi pelengkap sistem eksisiting yaitu terestrial dan satelit. Teknologi seluler 5G merupakan salah satu aplikasi yang dapat digunakan dalam sistem HAPS. Namun dapat menyebabkan interferensi jika mencapai kapasitas maksimum dan dapat diatasi dengan teknik multispot beam dan power control. Penelitian ini bertujuan untuk mengevaluasi kapasitas $5 \mathrm{G}$ seluler dalam sistem HAPS tunggal di mana bandwidth yang digunakan adalah $0,1 \mathrm{GHz}$ dan $1 \mathrm{GHz}$. Probabilitas outage menggunakan bandwidth 0,1 GHz menghasilkan kapasitas dalam sistem HAPS tunggal, maksimum 550 user dan saat menggunakan $1 \mathrm{GHz}$ maka maksimum jumlah user adalah 5500 dalam referensi sel saat ditinjau dari hasil simulasi (Iskandar, 2018).

Menurut penelitian yang berjudul "Analisis Performansi Sistem Jaringan Femtocell 5G Berbasis Simulasi" oleh Ramadhani menyebutkan bahwa dalam penelitian ini, peneliti mempelajari skenario dimensi jaringan yang sesuai dalam mencapai data rate yang ditargetkan sesuai dengan standar $5 \mathrm{G}$ pada suatu tempat atau lokasi dengan kepadatan user yang cukup tinggi yang difokuskan pada jaringan femtocell, yaitu small base station (akses poin) yang didesain untuk penggunaan indoor dengan konsumsi daya yang rendah. Terdapat tiga skenario antena (Multi-Input Multi-Output) MIMO yang berbeda dalam penelitian ini. Dimana dari hasil simulasi diperoleh bahwa dengan konfigurasi MIMO 16X16, sistem jaringan telah mampu menyediakan data rate sebesar 1 Gbps untuk semua user serta menunjukkan hasil yang terbaik jika dibandingkan dengan $\begin{array}{llllll}\text { konfigurasi } & \text { MIMO } & \text { 4X4 dan } & \text { MIMO } & \text { 8X8 }\end{array}$ (Ramadhani, 2020).

Penelitian yang berjudul "Komunikasi Deviceto-Device pada Jaringan Seluler 5G menggunakan mmWave" oleh Mulyadi dan Usman membahas tentang komunikasi dari perangkat ke perangkat lain pada jaringan seluler $5 \mathrm{G}$ menggunakan mmWave dimana teknologi seluler 5G akan menjadi solusi untuk mengatasi keterbatasan jangkauan seluler dan kapasitas layanan. komunikasi D2D (Device-toDevice) dapat digunakan dalam berbagai aplikasi namun rentan menyebabkan interferensi antar sinyal dalam satu sel, sehingga diperlukan pengelolaan sumber daya yang efektif. Penggunaan D2D juga akan meningkatkan kompleksitas suatu sistem seluler, baik dari segi manajemen resource, interferensi, dan juga routing yang dibutuhkan. Beberapa penelitian telah dilakukan untuk menciptakan komunikasi D2D yang dapat diimplementasikan secara efektif pada 5G. Salah satunya adalah penelitian untuk menyempurnakan skema load balancing yang merupakan salah satu fungsi yang diperoleh dari komunikasi D2D. Load balancing adalah distribusi beban lalu lintas seluler, menggunakan komunikasi D2D beban lalu lintas disalurkan ke komunikasi antar perangkat dan mengurangi beban pada jaringan utama (Mulyadi dan Usman, 2020). 
Penelitian oleh Zainal, Yamada dan Kamarudin yang berjudul "Low Sidelobe And Wideband Characteristics Of Density Tapered Arrays For $5 g$ Mobile Systems" memaparkan tentang antena dari Conventional mobile base station terdiri dari antena linear array dengan jarak yang sama. Untuk mencapai low side dari karakteristik lobus, koefisien eksitasi untuk array elemen ditentukan oleh feeding network. Karena kompleksitas dari feeding network, maka rentang frekuensi yang berlaku dibatasi. Dalam sistem seluler $5 \mathrm{G}$, operasi multi frequency band akan di request. Untuk mencapai karakteristik sidelobe yang rendah dan frekuensi yang lebar, maka konfigurasi density tapered array cukup menjanjikan. Karena koefisien eksitasi bersifat seragam, maka feeding network tidak memiliki ketergantungan terhadap frekuensi dan diharapkan menghasilkan aplikasi jangkauan frekuensi yang luas. Dalam penelitian ini, dilakukan penyelidikan tentang kemampuan dan metode desain karakteristik sidelobe yang rendah. Dengan pengurangan kepadatan, maka level sidelobe berkurang dari $13 \mathrm{~dB}$ menjadi $-16 \mathrm{~dB}$. Adapun karakteristik wide band, karakteristik sidelobe rendah dipertahankan selama operasi $28 \mathrm{GHz}$ hingga $56 \mathrm{GHz}$ (Zainal, Yamada dan Kamarudin, 2016).

Sementara penelitian yang berjudul "Pengenalan Teknologi 5G (Generasi Ke 5) Pada Sebuah Sistem Antena Untuk Siswa/i SMA Di Kembangan Utara Universitas Mercu Buana Jakarta Barat" oleh Firdausi merupakan penelitian hasil dari pengabdian Masyarakat yang dilaksanakan untuk pengenalan teknologi $5 \mathrm{G}$ pada sistem antena untuk para siswa di SMA Kembangan Utara. Penelitian ini dilakukan di sebuah laboratorium pada jurusan Teknik Elektro, Univ. Mercu Buana Jakarta. Tujuannya adalah agar para praktisi di bidang information technology mendapat pengetahuan terbaru terkait teknologi yang saat ini sedang berkembang dan berlomba-lomba melakukan penelitian agar mengetauhi perkembangan dari teknologi selular 5G. Hasil akhir yang diharapkan adalah audiens paham tentang sistem antena serta teknologi 5G (Firdausi, 2019).

Menurut penelitian yang berjudul "Pengenalan Teknologi Telekomunikasi pada Generasi Muda dalam Menyongsong Era Baru Teknologi Generasi Kelima (5G)" oleh Alfaresi perkembangan teknologi telekomunikasi telah berkembang selaras dengan peningkatan traffic data internet yang tinggi, hal ini disebabkan penggunaan data internet oleh semua kalangan usia. Dengan adanya persaingan global yang sangat ketat di masa depan akan pengetahuan tentang teknologi telekomunikasi, mendasari dilakukannya penelitian ini kepada para generasi muda untuk diberikan pengetahuan dan edukasi mengenai teknologi telekomunikasi dalam menyongsong era 5G agar memiliki daya saing menghadapi persaingan ke depannya. Metode yang digunakan yaitu penjelasan materi secara langsung kepada siswa dengan pelaksanaan pre dan post-test sebagai evaluasi kegiatan. Kegiatan ini dilaksanakan di SMP Muhammadiyah 6 Palembang dengan durasi kegiatan selama 1 hari. Pada kegiatan pengabdian ini disimpulkan bahwa hampir seluruh siswa telah menggunakan Internet dengan berbagai tujuan baik dalam penggunaan media sosial, email maupun social message. Dari hasil evaluasi pre dan post tes didapatkan bahwa tingkat pemahaman siswa tentang telekomunikasi mengalami peningkatan (Alfaresi, 2020).

Penelitian oleh Huo yang berjudul "Enabling Multi-Functional 5G and Beyond UE: A Survey and Tutorial", Penelitian dan pengembangan generasi kelima (5G) telah didorong oleh banyak terobosan baru di berbagai bidang seperti Carrier Aggregation (CA), Licensed Assisted Access (LAA), Massive MIMO (MaMi), Cooperative Spectrum Sensing (CSS), Compressive Sensing (CS) dan lain lain. Hal ini memberikan harapan dan inspirasi untuk mengatasi tantangan dalam implementasi jaringan 5G. Namun, pada User Equipment (UE), anggaran desain yang terbatas dan sumber daya perangkat keras justru membawa beberapa masalah dan tantangan baru dalam implementasi multi-standar dan multi-fungsi dari komunikasi nirkabel. (Huo, 2019).

Menurut penelitian oleh Maksymyuk, Gazda, Luntovskyy dan Klymash yang berjudul "Artificial Intelligence based 5G Coverage Design and optimization using Deep Generative Adversarial Neural Networks", dalam implementasi jaringan 5G memerlukan perombakan pemikiran ulang untuk memberikan user experience yang sangat tinggi di seluruh cakupan radius sel. Dalam penelitian ini, diusulkan pendekatan baru untuk perencanaan cakupan micro cell dan optimalisasi kinerja untuk jaringan $5 \mathrm{G}$ berdasarkan kecerdasan buatan (AI). AI dikembangkan dengan cara menambahkan pengetahuan dan pengalaman riset, lalu dikirimkan ke setiap SDN controller lokal dalam bentuk yang telah disederhanakan. Pendekatan yang diusulkan memungkinkan melatih deep neural networks secara efektif dengan menggunakan Generative Adversarial Networks (GAN) untuk berbagai macam topologi dan kinerja jaringan menggunakan data yang cukup mirip dengan kondisi riil. Pendekatan ini bertujuan untuk memaksimalkan cakupan jaringan walaupun data input yang digunakan tidak sama persis dengan kondisi riil. Sistem yang dihasilkan menunjukan cakupan dan throughput dengan kualitas yang baik serta tingkat kompleksitas yang rendah agar mudah dipahami (Maksymyuk, Gazda, Luntovskyy dan Klymash, 2018)

Sementara penelitian oleh Admaja yang berjudul "Pemetaan Riset Teknologi 5G", tujuan penelitian ini adalah untuk menerangkan bagaimana perkembangan teknologi selular 5G dari tahun 2013 hingga 2017. Melalui gambaran ini sehingga diharapkan dapat membantu dalam menentukan 
kontribusi yang harus dilakukan dalam implementasi teknologi selular 5G. Basis data online dari salah satu sumber diambil kemudian dilakukan pemetaan, basis data ini adalah basis data Scopus. Secara kualitatif dari hasil akhir diterangkan dengan melihat tingkat dari kontribusi, jumlah dari sitasi kolaborasi sang penulis, dan lainya (admaja, 2018).

Menurut penelitian oleh yang berjudul "Potensi Riset Transmisi Radio Untuk Adopsi Teknologi 5G Dan Teknologi Seterusnya" menyatakan bahwa penelitian ini bertujuan untuk menemukan strategi sebagai langkah penerapan teknologi untuk mengadopsi teknologi $5 \mathrm{G}$ di indonesia dengan metode TAIDA (tracking, analyzing, imaging, deciding, acting) serta SWOT seperti pada kombinasi M-MIMO dan beam forming adaptif antena cerdas. Hal yang berperan sangat penting yaitu support untuk regulasi pada riset serta peningkatan kolaborasi penelitian sesama institusi di bidang transmisi radio untuk mengadopsi teknologi selular 5G yang akan hadir di Indonesia (Hidayat, 2018).

Penelitian yang berjudul "Masa Depan Jaringan 5G dan Perilaku Komunikasi Digital" oleh Yuniarto menyatakan bahwa saat ini masyarakat menikmati koneksi jaringan 4G dengan kecepataan transmisi data yang lebih baik dibanding generasi 3G. Jaringan 5G merupakan generasi ke lima dimana teknologi generasi ini resmi diliris pada 2020. Penelitian ini menitikberatkan tentang perilaku masyarakat dalam bermedia, khususnya dalam dunia digital. Penelitian ini menggunakan survei tatap muka dan jajak pendapat melalui telepon, dimana hasilnya menunjukkan perilaku masyarakat bahwa gadget merupakan perangkat penting bagi masyarakat sebagai alat komunikasi, Hadirnya jaringan 5G akan banyak membuka peluang masyrakat untuk mendapatkan beragam informasi secara cepat. Di sisi produsen konten informasi dan berita, jaringan $5 \mathrm{G}$ berguna untuk memperbanyak jenis konten yang diproduksi. Kendati demikian tetap dibutuhkan undang-undang untuk mengatur pemberlakukan dan penggunaan jaringan 5G (Yuniarto, 2019).

Menurut penelitian yang berjudul "Wireless Sensor Network Exploiting High Altitude Platform in $5 G$ Network" yang ditulis oleh Mahyastuty, Laju perkembangan transformasi sosial-ekonomi dan teknologi merupakan penyebab utama perubahan dari bisnis pada bidang jaringan 5G, maka jaringan 5G diharapkan memiliki laju pengiriman data yang lebih cepat dan menjadi solusi dari beberapa kasus dari berbagai aplikasi, contohnya adalah massive Machine Type Communication (MTC). Jaringan sensor nirkabel (JSN) merupakan salah satu aplikasi massive MTC. Tantangannnya adalah bagaimana jaringan seluler $5 \mathrm{G}$ memodelkan arsitektur/topologi agar mendukung JSN serta menghasilkan efisiensi konsumsi energi (Mahyastuty, 2017).
Penelitian oleh Raghavan yang berjudul "Evolution of Physical-Layer Communications Research in the Post-5G Era" menyatakan tentang upaya standardisasi seluler generasi kelima (5G) yang berkembang pada Third Generation Partnership Project (3GPP) menjadi fokus sejumlah pertanyaan tentang masalah penelitian yang relevan dalam physical layer komunikasi untuk dipelajari oleh para akademisi dan industri. Untuk menjawab pertanyaan ini, para peneliti menunjukkan bahwa kecepatan data peak download data rates untuk WiFi dan sistem seluler telah meningkat secara eksponensial dengan waktu selama 25 tahun terakhir. Sementara mengikuti tren seluler historis akan dimungkinkan dalam waktu dekat dengan bandwidth yang rendah dan ekspansi dari kompleksitas hardware, akan membutuhkan pertambahan bandwidth yang signifikan. Dalam paper ini disimpulkan dengan serangkaian implikasi untuk prospek penelitian masa depan pada lapisan fisik (physical-layer), termasuk key use-cases, beberapa kemungkinan pada research policy initiatives, dan beberapa perubahan struktural yang diperlukan di departemen telekomunikasi di universitas (Raghavan, 2019).

Menurut penelitian Lufianawati dan Wicaksana yang berjudul "Analisis Kesiapan Indonesia dalam Menghadapi Teknologi 5G", yaitu beberapa penelitian sebelumnya menyimpulkan bahwa 5G dapat diimplementasikan di Indonesia. Namun, dibutuhkan banyak persiapan. Dimana penelitian ini menganalisis tentang kesiapan Indonesia dalam menghadapi teknologi 5G melalui penyusunan strategi-strategi menggunakan metode SWOT. Salah satu strategi yang telah dianalisis adalah strategi SO yaitu memaksimalkan aplikasi yang dapat dilayani jaringan 5G untuk menarik minat konsumen sehingga terjadi peningkatan jumlah pengguna internet, jumlah pengguna smartphone, trafik data, dan jumlah perangkat yang terhubung IoT di Indonesia (Lufianawati dan Wicaksana, 2020).

Penelitian serupa oleh Kadek Linda Krisna Dewi yang berjudul "Perencanaan Coverage Pada Sistem Long Term Evolution $700 \mathrm{MHz}$ Di Kota Denpasar" Pada penelitian ini membahas perencanaan jaringan LTE pada frekuensi $700 \mathrm{MHz}$ dengan lebar bandwidth yang digunakan adalah 10 $\mathrm{MHz}$ dan memanfaatkan menara rooftop. Spesifikasi $e N o d e B$ yang digunakan adalah berasal dari weblokasi resmi 3GPP. Hasil dari penelitian ini adalah untuk mengetahui luas coverage dari menara yaitu seluas $2,6398 \mathrm{~km}^{2}$ untuk ketinggian 13 meter, $3,8191 \mathrm{~km}^{2}$ untuk ketinggian 18 meter dan 4,7970 $\mathrm{km}^{2}$ untuk ketinggian 22 meter pada daerah urban. Untuk sub urban dengan luas coverage yakni masing masing $8,9131 \mathrm{~km}^{2}, 12,8970 \mathrm{~km}^{2}$ dan $16,1980 \mathrm{~km}^{2}$ untuk ketinggian 13, 18 dan 22 meter. Dan pembangunan lokasi pada balai banjar memberikan kontribusi sebesar (80\%) untuk 
pengkategorian urban maupun sub urban (Dewi, 2014).

Hal ini mencerminkan bahwa penempatan menara rooftop dibalai banjar untuk sistem LTE sudah cukup sesuai, namun belum dapat mencakup seluruh Kota Denpasar secara maksimal. Di sisi lain, jaringan sistem $5 \mathrm{G}$ memiliki performansi yang lebih baik dan stabil dibandingkan dengan sistem 4G, terutama pada peak rate dan latency serta throughput yang dihasilkan oleh sebuah node sistem 5G (yang terdiri dari 80 microcell) sebesar 416000 Mbps (Qorvo, 2017) merupakan 11,42 kali lebih besar daripada throughput dari node sistem LTE (Dahlman, Parkvall dan Skold, 2019). Berdasarkan hal tersebut, maka diperlukan kajian lebih lanjut terkait penelitian jaringan yang sesuai untuk menara rooftop agar dapat mencakup seluruh Kota Denpasar.

Beberapa ruang lingkup pada penelitian ini, yaitu sistem yang diteliti pada frekuensi $869 \mathrm{MHz}$ dimana frekuensi ini berasal dari band frekuensi yang telah ditetapkan oleh organisasi 3GPP seperti pada Tabel 1 (Dahlman, Parkvall dan Skold, 2019).

Kemudian parameter-parameter yang digunakan dalam perhitungan menggunakan parameter spesifikasi menara yang dikeluarkan dari standar 3GPP, penelitian yang dilakukan dan di analisis hanya pada data rate $256 \mathrm{kbps}$ arah downlink dan uplink, membahas analisis penerapan propagasi sistem $5 \mathrm{G}$ hanya pada persamaan rugirugi lintasan dengan pengaruh shadowing, jenis menara pada perencanaan adalah menara rooftop monopole, tidak memperhitungkan interferensi yang terjadi dan menggunakan software Google Earth sebagai software pemetaan.

Propagasi rugi-rugi lintasan ditandai dengan adanya perbedaan level daya yang diterima oleh MS (Mobile Station) terhadap EIRP (Effective Isotropic Radiated Power) yang dipancarkan oleh BS (Base Station) (Triana dan Pinem, 2015). Sedangkan persamaan rugi-rugi lintasan dengan pengaruh shadowing adalah sebuah persamaan rugi rugi lintasan untuk area luar gedung dengan pertimbangan penggunaan frekuensi yang fleksibel dan pada daerah urban, dimana mengasumsikan bahwa daya pancar $\left(P_{t}\right)$, gain antena pemancar $\left(G_{t}\right)$ dan penerima $\left(G_{r}\right)$ untuk semua node adalah sama. Sedangkan $P_{r}$ merupakan daya terima melalui kanal nirkabel sepanjang nilai $d$ (Gunantara dan Hendrantoro, 2013). Untuk persamaanya dapat dilihat pada persamaan (3).

\section{METODE PENELITIAN}

Penelitian dilakukan pada wilayah kota Denpasar, dimulai Bulan Mei 2019. Sumber data yang diperoleh dikelompokan terdiri dari data sekunder maupun data primer. Data primer ialah data yang didapatkan langsung dengan mensurvey lokasi, yaitu berupa koordinat tiap banjar dan titik penyebaran menara rooftop untuk wilayah Denpasar. Data sekunder diperoleh dari literatur dengan referensi buku, jurnal, paper dan hasil browsing di internet yang menunjang analisa selama penelitian berlangsung. Dalam penelitian ini langkah-langkah yang dilakukan dapat dilihat pada Gambar 3. Langkah awal yang dilakukan adalah menentukan parameter yang akan digunakan saat analisa yaitu frekuensi, fade margin, $R_{x s}$ sensitivity, kuat sinyal yang diterima kuat sinyal yang dikirim, penguatan (gain) antena pemancar, penguatan (gain) antena penerima, panjang gelombang elektromagnetik, shadowing loss dan luas kota denpasar. Selanjutnya menghitung jari-jari dengan model propagasi rugi-rugi lintasan dan shadowing, menmghitung coverage, menghitung jumlah menara rooftop di Kota Denpasar, dan pemetaan menara rooftop di Kota Denpasar menggunakan Google Earth.

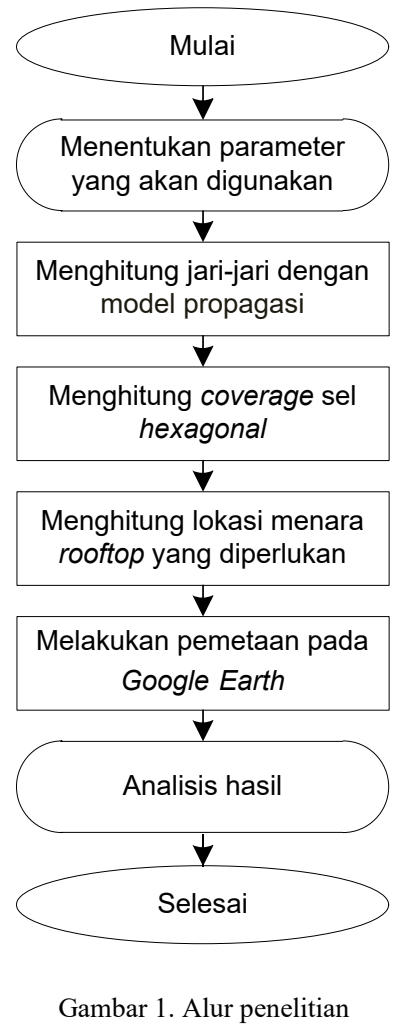

\section{TINJAUAN PUSTAKA}

\subsection{Generasi Kelima (5G)}

Sampai dengan saat ini standar yang berlaku di dunia untuk teknologi 5G masih belum dikomersialkan karena masih dalam tahap uji coba, Tetapi sudah banyak para produser telekomunikasi di dunia bersaing mencari teknologi dengan persyaratan minimal untuk mengimplementasikan teknologi 5G. Arlokasirktur jaringan 5G terdiri dari C-RAN (Cloud Radio Access Network), Transport dan Core network. Lebih jelasnya dapat dilihat pada Gambar 1. 


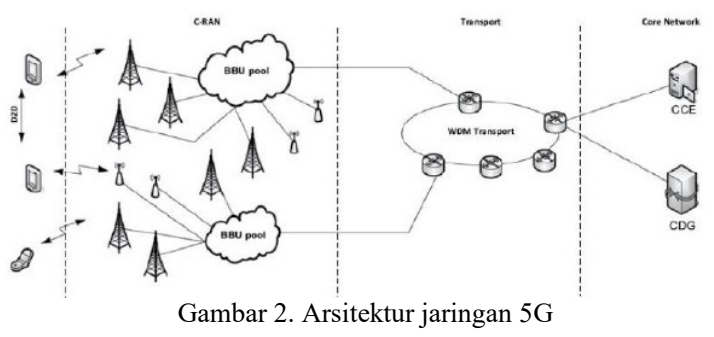

C-RAN adalah jaringan beraklokasiktur cloud computing-based untuk jaringan akses radio yang memungkinkan large-scale deployment dari jaringan yang di dukung oleh jaringan radio kolaboratif dan kemampuan virtualisasi real-time. RAN membuat koneksi atau komunikasi antara BTS dan end-users. BBU (Base Band Unit) yaitu berupa kumpulan beberapa port yang terkoneksikan pada semua device di Base Transceiver Station. Di sebuah bangunan Base Transceiver Station (BTS), BBU adalah sebuah main device dari kerja BTS tersebut. BBU berbentuk sebuah proccecor yang berfungsi untuk mengatur input dan output data, penggunaan dari frekuensi serta pengaturan dari fungsi cooler dan alarm. Proses kerja dari BBU di sebuah BTS berawal dari diterimanya rectifier input listrik DC yang berguna untuk menjalankan BBU serta menghidupkan seluruh modul di RFU (Radio Frekuensi Unit). Dalam arlokasiktur C-RAN, traffic data dari BBU diteruskan dari sebuah BTS ke centralized control and processing BTS atau disebut dengan BBU pool. BBU pool terhubung ke jaringan lainnya menggunakan serat optik berkecepatan tinggi, hal ini dapat berfungsi untuk memaksimalkan jarak antar sel. C-RAN berperan sangat penting dalam perkembangan teknologi nirkabel di masa depan untuk jaringan 5G dan IoT (Internet $O f$ Things). Dengan penyebaran yang lebih mudah dan kemampuan penskalaan, transisi dari jaringan LTE ke $5 \mathrm{G}$ akan sangat bergantung pada pengembangan C-RAN. Selanjutnya terdapat Transport layer, CRAN adalah evolusi dari sistem komunikasi nirkabel saat ini dan menggunakan standar Common Public Radio Interface (CPRI) terbaru, teknologi Coarse atau Dense Wavelength Division Multiplexing (CWDM / DWDM) dan transmisi millimeter-wave (MM wave) untuk sinyal jarak jauh. Yang terakhir terdapat Core Network, jaringan yang dapat dibagi menjadi 2, yaitu Combined Control Entity (CCE) dan Combined Data Gateway (CDG). Dimana CCE berfungsi untuk mengontrol fungsi jaringan core $5 \mathrm{G}$ yaitu MME, SGW-C dan PGW-C. Sedangkan CDG berfungsi untuk melakukan data forwarding functions dari jaringan core $5 \mathrm{G}$ yaitu SGW-D, and PGW-D (Asif, 2019). Sistem jaringan 5G memiliki banyak kegunaan, diantaranya Autonomous vehicle control atau kendaraan dengan kemudi otomatis, Emergency Communication, High-speed train dan lain lain (Osseiran, Monserrat dan Marsch, 2016). Untuk parameter-parameter yang digunakan dalam perhitungan menggunakan parameter spesifikasi menara yang dikeluarkan oleh 3GPP pada Tabel 2 (3GPP, 2019).

\begin{tabular}{llll}
\multicolumn{4}{c}{ Tabel 1. Pita frekuensi Jaringan 5G } \\
\hline $\begin{array}{l}\text { Pita } \\
\text { frekue } \\
\text { nsi }\end{array}$ & $\begin{array}{l}\text { Uplink } \\
(\mathrm{MHz})\end{array}$ & $\begin{array}{l}\text { Downlink } \\
(\mathrm{MHz})\end{array}$ & $\begin{array}{l}\text { Main Region } \\
(\mathrm{s})\end{array}$ \\
\hline $5 G$ & $824-849$ & $869-894$ & $\begin{array}{l}\text { Americas, } \\
\text { Asia }\end{array}$ \\
\hline
\end{tabular}

Tabel 2. Parameter spesifikasi menara rooftop

\begin{tabular}{lll}
\hline Parameter & Nilai Uplink & $\begin{array}{l}\text { Nilai } \\
\text { Downlink }\end{array}$ \\
\hline Data Rate & $256 \mathrm{Kbps}$ \\
\hline Transmitter (Tx) & \multicolumn{2}{l}{} \\
\hline Tx Antenna Gain & $0 \mathrm{dBi}$ & $8 \mathrm{dBi}$ \\
Cable Loss & $1 \mathrm{~dB}$ & $3 \mathrm{~dB}$ \\
\hline Receiver (Rx) & & \\
\hline Antenna Gain & $8 \mathrm{dBi}$ & $0 \mathrm{dBi}$ \\
Body Loss & $3 \mathrm{~dB}$ & $1 \mathrm{~dB}$ \\
Receiver Noise Figure & $5 \mathrm{~dB}$ & $7 \mathrm{~dB}$ \\
Receiver Implementation & $2 \mathrm{~dB}$ & $2 \mathrm{~dB}$ \\
Margin & & \\
Receiver Sensitivity for Data & $-96,93 \mathrm{dBm}$ & $-93,35$ \\
Channel & $4,89 \mathrm{~dB}$ & $\mathrm{dBm}$ \\
Shadow Fading Margin for & & $4,89 \mathrm{~dB}$ \\
Data Channel & $9 \mathrm{~dB}$ & \\
Penetration Margin & & $9 \quad \mathrm{~dB}$ \\
& &
\end{tabular}

\subsection{Cell}

Cell adalah sebuah area cakupan dari sebuah BS (Base Station). Pembagian sel pada layout perencanaan dimodelkan dalam bentuk hexagonal, dengan tujuan agar lebih rmudah dalam penggambaran layout. Jika diasumsikan bentuk sel adalah hexagonal,, dengan $R$ adalah jari-jari sel, maka untuk bentuk sel dapat dilihat seperti Gambar 2 (Sudiarta, 2009). Sehingga untuk mencari luas sel yang berbentuk hexagonal seperti Gambar 2 dapat menggunakan persamaan:

$L=2,6 R^{2}$

dengan $R=$ jari-jari sel $(\mathrm{km})$

Dan banyaknya sel yang diperlukan suatu daerah dirumuskan oleh persamaan berikut:

$\sum$ Lokasi sel $=\frac{\text { Luas Wilayah Kota Denpasar }}{\text { Luas Coverage Sel }}$

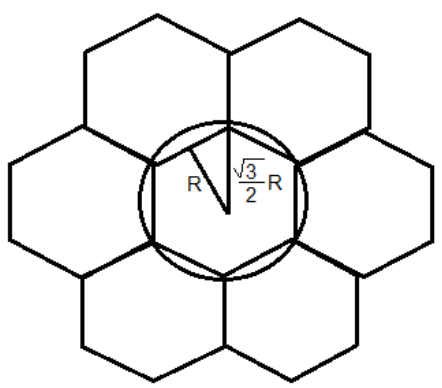

Gambar 3. Sel Hexagonal 


\subsection{Propagasi}

Propagasi yaitu sebuah proses perambatan dari gelombang elektromagnetik, berawal pada suatu lokasi ke lokasi lainnya. Sedangkan Fading ialah sumber utama yang mengganggu performansi sistem. Fading dapat menyebabkan kondisi dimana penerimaan kualitas sebuah sinyal menjadi tidak layak untuk di proses lebih lanjut. Setiap proses propagasi akan menimbulkan rugi-rugi propagasi (Sudiarta, 2013). Dalam penelitian ini akan memberikan gambaran nilai data rate $256 \mathrm{Kbps}$, baik pada arah downlink dan uplink. Model propagasi yang akan digunakan adalah model persamaan rugi-rugi lintasan dengan pengaruh shadowing. yaitu sebuah persamaan rugi rugi lintasan untuk area luar gedung dengan frekuensi yang fleksibel dan pada daerah urban sehingga sesuai dengan kota Denpasar yang merupakan daerah urban. Persamaan tersebut adalah sebagai berikut (Gunantara dan Hendrantoro, 2013):

$P_{r}=P_{t} G_{t} G_{r}\left(\frac{\lambda}{4 \pi}\right)^{2} d^{-\alpha} 10 \frac{X_{\varphi}}{10}$

di mana:

$P_{r} \quad=$ Kuat sinyal yang diterima $(\mathrm{W})$

$P_{t} \quad=$ Kuat sinyal yang dikirim $(\mathrm{W})$

$G_{t}=$ Penguatan (gain) antena pemancar (W)

$G_{r} \quad=$ Penguatan (gain) antena penerima (W)

$\lambda=$ Panjang gelombang elektromagnetik (m)

$d=$ Jarak antara transmitter dengan receiver $(\mathrm{km})$

$\alpha=4$ (untuk daerah urban)

$X_{\varphi}=$ Shadowing loss $(\mathrm{dB})$ yang bernilai $0,8 \mathrm{~dB}$

Dengan nilai panjang gelombang elektromagnetik ( $\lambda$ ) sebagai berikut (Amos, 1996):

$$
\lambda=\frac{C}{f}
$$

di mana:

$$
\begin{array}{ll}
C & =\text { Kecepatan cahaya }\left(3 \times 10^{8} \mathrm{~m} / \mathrm{s}\right) \\
f & =\text { Frekuensi }(\mathrm{Hz})
\end{array}
$$

\subsection{Fade Margin}

Fade Margin adalah tingkat daya cadangan yang diterima, dimana harus atau melebihi dari nilai yang diperlukan untuk tingkat minimum kinerja dari sistem yang ditentukan. Fade Margin dirumuskan sebagai persamaan sebagai berikut (Campbell Scientific. Inc, 2016):

Fade Margin $=P_{r}-R_{x s}$

di mana:

Fade Margin = Margin yang sampai pada penerima pada saat implementasi $(\mathrm{dB})$

$$
\begin{array}{ll}
P_{r} & =\text { Kuat sinyal yang diterima }(\mathrm{dBm}) \\
R_{x s}= & \text { Nilai sensitivitas minimum yang } \\
& \text { dapat diterima }(\mathrm{dBm})
\end{array}
$$

\subsection{Google Earth}

Google Earth adalah sebuah aplikasi yang dirilis oleh Keyhole, Inc dalam bentuk Earth Viewer. Program ini terbagi menjadi tiga versi lisensi yang berbeda yaitu Google Earth, Google Earth Plus, dan Google Earth Pro. Untuk dapat menggunakan aplikasi ini, komputer wajib terhubung/memiliki koneksi internet (Maestro, 2010).

\section{HASIL DAN PEMBAHASAN}

Penelitian terbagi atas 3 alur utama yaitu alur perhitungan coverage, alur perhitungan jumlah menara rooftop secara teoritis di kota Denpasar dan alur pemetaan menara rooftop di Kota Denpasar menggunakan Google Earth.

\subsection{Perhitungan Luas Coverage}

Tahap ini dimulai dengan perhitungan nilai panjang gelombang elektromagnetik $(\lambda)$ menggunakan persamaan (4), perhitungan nilai kuat sinyal yang diterima $\left(\mathrm{P}_{\mathrm{r}}\right)$ dengan persamaan (5), perhitungan nilai penguatan / gain antena pemancar $\left(\mathrm{G}_{\mathrm{t}}\right)$ dan perhitungan nilai penguatan / gain antena penerima $\left(\mathrm{G}_{\mathrm{r}}\right)$ berdasarkan Tabel 2, maka di temukan jarak dari sel (d), yaitu pada Tabel 3.

Dari Tabel 3 terlihat perbedaan nilai jari-jari yang dihasilkan pada kedua sistem dimana jari-jari arah downlink terlihat lebih kecil, hal ini dikarenakan kuat sinyal yang diterima $\left(\mathrm{P}_{\mathrm{r}}\right)$ pada arah downlink bernilai lebih besar serta gain antena penerima $\left(\mathrm{G}_{\mathrm{r}}\right)$ bernilai lebih kecil dibandingkan arah uplink. Dimana nilai jari-jari akan berbanding lurus dengan nilai gain antena penerima $\left(\mathrm{G}_{\mathrm{r}}\right)$ serta berbanding terbalik dengan nilai kuat sinyal yang diterima $\left(\mathrm{P}_{\mathrm{r}}\right)$

\begin{tabular}{lllll}
\multicolumn{5}{l}{ Tabel 3. Perhitungan Jarak Pada Arah Downlink Dan Uplink } \\
\hline Link & $\mathrm{P}_{\mathrm{r}}(\mathrm{W})$ & $\mathrm{G}_{\mathrm{t}}(\mathrm{W})$ & $\mathrm{G}_{\mathrm{r}}(\mathrm{W})$ & $\mathrm{d}(\mathrm{m})$ \\
\hline Uplink & $3,2137 \mathrm{x}$ & 0,794 & 0,041 & 990,8 \\
& $10^{-13}$ & & & \\
Downlink & $7,3282 \times$ & 3,162 & 0,006 & 704,5 \\
& $10^{-13}$ & & & \\
\hline
\end{tabular}

Dengan adanya perbedaan nilai jari-jari yang dihasilkan pada Tabel 3, maka dipilih salah satu dan kemudian digunakan sebagai acuan untuk perencanaan coverage pada sistem $5 \mathrm{G}$ di kota Denpasar ini, yaitu jari-jari yang dihasilkan pada sistem downlink $(70,4479 \mathrm{~m})$ atau coverage dengan limited downlink. Karena jari-jari yang lebih kecil akan menghasilkan coverage yang lebih kecil pula. Sehingga ketika limited downlink terjadi maka komunikasi dua arah pada sistem tetap bisa dilakukan. Baik komunikasi dari user ke base 
station ataupun untuk sistem komunikasi dari base station ke user walaupun dengan jarak yang minimum. Sedangkan apabila jari-jari yang digunakan dari arah uplink, belum tentu bisa terjadi komunikasi dua arah atau mungkin tidak terjadi komunikasi sama sekali dari user ke base station karena jarak yang diperlukan untuk komunikasi downlink lebih kecil dibandingkan dengan uplink Sedangkan untuk menghitung digunakan persamaan (1) sehingga di dapat luas coverage sel yaitu seluas $0,0129 \mathrm{~km}^{2}$.

\subsection{Perhitungan Jumlah Menara Rooftop Secara Teoritis Di Kota Denpasar}

Penelitian dilanjutkan dengan perhitungan jumlah menara rooftop secara teoritis di kota Denpasar menggunakan persamaan (2). Luas coverage sel adalah $0,0129 \mathrm{~km}^{2}$ dan luas kota Denpasar adalah $130,48 \mathrm{~km}^{2}$ maka jumlah sel yang diperlukan secara teoritis untuk mencakup seluruh kawasan kota Denpasar yaitu 10115 buah.

\subsection{Pemetaan Menara Rooftop Di Kota Denpasar Menggunakan Google Earth}

Pemetaan ini di mulai dari balai banjar balun yang terletak pada longitude $115,186828^{\circ}$ dan latidute $-8.64875^{\circ}$ serta Banjar Sari yang terletak pada longitude $115,20205^{\circ}$ dan latidute $-8,652116^{\circ}$, karena kedua banjar ini merupakan balai banjar eksisting yang telah di instalasi lokasi menara rooftop. Gambar 4 merupakan hasil pemetaan awal menggunakan Google Earth dimana dapat dilihat bahwa pemetaan masih memiliki banyak daerah blank spot. Dari total 393 balai banjar yang dapat digunakan, terdapat 366 balai banjar yang akan digunakan untuk pembangunan lokasi dalam pemetaan.

Pada Gambar 4 terlihat masih banyak terdapat daerah blank spot pada pemetaan kawasan kota Denpasar. Dari seluruh daerah blank spot, tidak semua daerah tersebut merupakan area pemukiman penduduk / area perumahan, terdapat beberapa area yang merupakan persawahan, perladangan, hutan dan areal hijau lainnya. Untuk memperkecil daerah blank spot tersebut, maka diperlukan sebuah solusi untuk mencakup kawasan tersebut. Dengan menggunakan pendekatan sel hexagonal akan di cari solusi untuk mencakup daerah blank spot tersebut, yaitu dengan melakukan pembangunan lokasi lainnya di luar daerah balai banjar, baik di gedung gedung bangunan / kantoran maupun di perumahan warga. Penempatan lokasi baru ditempatkan diluar daerah balai banjar karena titik lokasi balai banjar tidak dapat lagi mencakup lokasi blank spot tersebut.

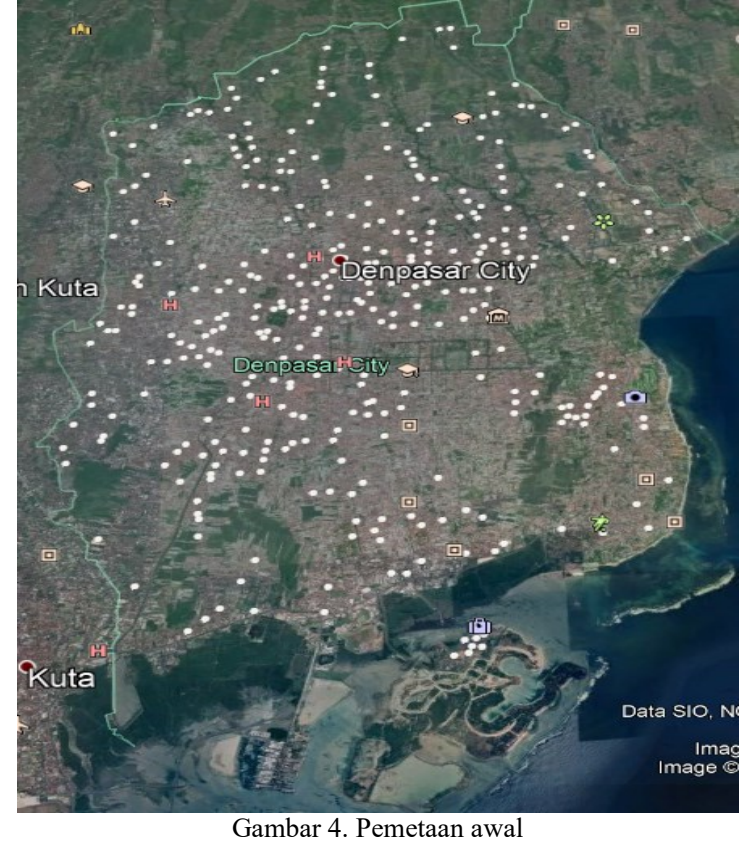

Namun sebelum melakukan penempatan lokasi baru, harus dilakukan pengukuran langsung ke daerah - daerah blank spot tersebut, untuk membuktikan bahwa daerah tersebut memang termasuk ke dalam daerah yang belum tercakup. Untuk melihat bagaimana hasil pemetaan jika dilakukan penempatan lokasi baru diluar daerah balai banjar, maka diperlukan kelanjutan pemetaan guna untuk melihat coverage yang dihasilkan beserta jumlah perkiraan lokasi yang dibutuhkan untuk lokasi diluar daerah balai banjar. Hasil pemetaan untuk di luar kawasan balai banjar dapat dilihat pada Gambar 5 dimana terdapat 11.550 lokasi baru yang dipetakan diluar daerah balai banjar yang diperlukan untuk mencakup kawasan daerah kota Denpasar. Dari Gambar 5 dapat di lihat bahwa pemetaan yang dilakukan setelah menambahkan lokasi diluar daerah balai banjar tidak menghasilkan daerah blank spot sama sekali. Hasil tersebut dapat dilihat pada Tabel 4.

Dari Tabel 4 dapat dilihat bahwa diperlukan total 11916 lokasi untuk mencakup seluruh kawasan kota Denpasar, dimana dari 11.916 lokasi tersebut terdiri dari 366 lokasi $(3,07 \%)$ pada kawasan balai banjar dan 11.550 lokasi $(96,93 \%)$ pada kawasan di luar balai banjar. Hasil ini menunjukkan bahwa dari seluruh lokasi yang digunakan untuk mencakup kawasan kota Denpasar, sebanyak 366 atau 3,07\% memanfaatkan lokasi balai banjar sebagai lahan lokasi menara rooftop sedangkan 11.550 atau 96,93\% ditempatkan diluar kawasan balai banjar.

\begin{tabular}{lccc}
\multicolumn{3}{c}{ Tabel 4 Jumlah Lokasi Pemetaan } \\
\hline \multicolumn{3}{c}{ Parameter } & \multicolumn{3}{c}{ Jumlah lokasi (buah) } \\
\hline $\begin{array}{l}\text { Lokasi Pemetaan awal } \\
\text { Penambahan lokasi di }\end{array}$ luar & 1156 \\
kawasan balai banjar & & \\
$\begin{array}{l}\text { Total jumlah lokasi yang } \\
\text { digunakan untuk mencakup seluruh } \\
\text { kawasan kota Denpasar }\end{array}$ & 11916 \\
\hline
\end{tabular}




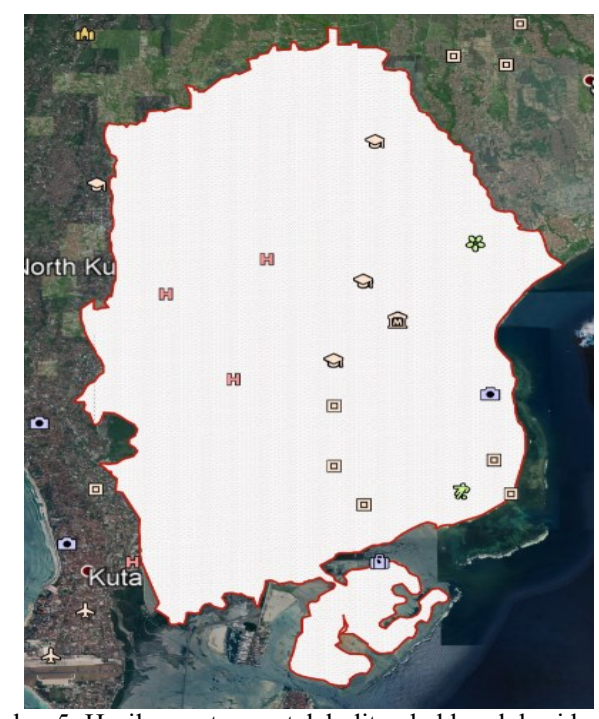

Gambar 5. Hasil pemetaan setelah ditambahkan lokasi baru di luar balai banjar

\section{KESIMPULAN}

Dari hasil analisis pada penelitian maka dapat disimpulkan yaitu pertama jari-jari sel yang dihasilkan menggunakan model propagasi persamaan rugi-rugi lintasan dengan pengaruh shadowing adalah 70,4479 m. Kedua, luas coverage sebesar $0,0129 \mathrm{~km}^{2}$. Ketiga, dari luas coverage maka dapat dihitung jumlah sel yang diperlukan secara teoritis untuk mencakup seluruh kawasan kota Denpasar yaitu sebanyak 10115 buah. Terakhir, hasil pemetaan yaitu diperlukan total 11916 lokasi untuk mencakup seluruh kawasan kota Denpasar, yang terdiri dari 366 lokasi dibangun di dalam kawasan balai banjar dan 11550 lokasi di luar kawasan balai banjar. Sehingga pemanfaatan lokasi balai banjar sebagai lahan lokasi menara rooftop adalah sebesar 3,07\% dan di luar balai banjar sebesar $96,93 \%$

\section{DAFTAR PUSTAKA}

3GPP., 2019. Link budget template - Channel Model A.

ADMAJA, A., 2018. Pemetaan Riset Teknologi 5G [5G Technology Research Mapping]. Buletin Pos dan Telekomunikasi, 16(1), p.27.

ALFARESI, B., ARDIANTO, F., HURAIRAH, M., BARLIAN, T. AND NOVERIANTY, R., 2020. Pengenalan Teknologi Telekomunikasi pada Generasi Muda dalam Menyongsong Era Baru Teknologi Generasi Kelima (5G). Jurnal Gema Ngabdi, 2(2), pp.161-169.

AMOS, 1996. Kamus elektronika. Jakarta: PT.Elex Media Komputindo
ASIF, S.Z. 2019. $5 G$ mobile communications concepts. Boca Raton: CRC Press/Taylor \& Francis Group

CAMPBELL SCIENTIFIC. INC.2016. The Link Budget and Fade Margin. Campbell Scientific. Inc

DAHLMAN, E., PARKVALL. S., SKOLD. J. 2019. 5G NR: The Next Generation Wireless Access Technology. United Kingdom: Elsevier.

DEWI, K.L.K. 2014. Perencanaan Coverage Pada Sistem Long Term Evolution $700 \mathrm{MHz}$ Di Kota Denpasar, [online] Tersedia di : < https://e-perpus.unud.ac.id $>$ [Diakses 20 November 2019]

FIRDAUSI, A., 2019. Pengenalan Teknologi 5G (Generasi Ke 5) Pada Sebuah Sistem Antena Untuk Siswa/I Sma Di Kembangan Utara Universitas Mercu Buana Jakarta Barat. Jurnal Abdi Masyarakat (JAM), 5(1), p.6.

FREEMAN, ROGER, L. 1999. Fundamental Of Telecommunications. England: John Wiley \& Sons

GUNANTARA, N., HENDRANTORO, G. 2013. Multi-Objective Cross-Layer Optimization For Selection Of Cooperative Path Pairs In Multihop Wireless Ad Hoc Networks: Journal Of Communications Software And Systems, Vol. 9, No. 3

HIDAYAT, R., 2018. Potensi Riset Transmisi Radio Untuk Adopsi Teknologi 5g Dan Teknologi Seterusnya. Creative Research Journal, 3(02), p.115.

HUO, Y., DONG, X., XU, W. AND YUEN, M., 2019. Enabling Multi-Functional 5G and Beyond User Equipment: A Survey and Tutorial. IEEE Access, 7, pp.116975117008.

ISKANDAR, I., 2018. 5G Capacity Design Based on User Demand in Single High Altitude Platform Network [Desain Kapasitas Seluler 5G Berdasarkan Permintaan Pengguna pada Jaringan High Altitude Platform Tunggal]. Buletin Pos dan Telekomunikasi, 16(2), p.125.

LUFIANAWATI, D.E.T., WICAKSANA, C.A. 2020. Analisis Kesiapan Indonesia dalam Menghadapi Teknologi 5G. Setrum: Sistem Kendali-Tenaga-elektronikatelekomunikasi-komputer, 9, p.17-23

MAESTRO. 2010. Apa Itu Google Earth?, [online] Tersedia di https://maestro.unud.ac.id/apa-itu-googleearth/> [Diakses 21 November 2019]

MAKSYMYUK, T., GAZDA, J., LUNTOVSKYY, A., AND KLYMASH, M. 2018. Artificial Intelligence based 5G Coverage Design and optimization using Deep Generative Adversarial Neural Networks. International 
Conference on Information and Telecommunication Technologies and Radio Electronics (UkrMiCo), Odessa, Ukraine, pp. 1-4.

MAHYASTUTY, V., ISKANDAR, I. AND HENDRAWAN, H., 2017. Wireless Sensor Network Exploiting High Altitude Platform in $5 \mathrm{G}$ Network. Buletin Pos dan Telekomunikasi, 15(1), p.55.

MULYADI, R. AND USMAN, U., 2020. Komunikasi Device-to-Device pada Jaringan Seluler $5 \mathrm{G}$ menggunakan mmWave. AVITEC, 2(1).

TRIANA, N., PINEM, M. 2015. Analisis model propagasi path loss semi-deterministik untuk aplikasi triple band di daerah urban metropolitan centre . 13.(35).13-18

OSSEIRAN, A., MONSERRAT, J.F., MARSCH, P. 2016. 5G Mobile and Wireless Communications Technology. United Kingdom: Cambridge University Press

QORVO. 2017. Getting to 5G: Comparing 4G and 5G System Requirements, [online] Tersedia di: > Http://qorvo.com/designhub/blog/getting-to-5g-comparing-4g-and5 g-system-requirements $>$ [Diakses 20 November 2019]

RAGHAVAN, V. AND LI, J., 2019. Evolution of Physical-Layer Communications Research in the Post-5G Era. IEEE Access, 7, pp.10392-10401.

RAMADHANI, U., 2020. Analisis Performansi Sistem Jaringan Femtocell 5G Berbasis Simulasi. Electrician, 14(1), pp.1-6.

SUDIARTA, P.K. 2013. Laporan Akhir Kajian Menara Rooftop.

YUNIARTO, T., 2019. Masa Depan Jaringan 5G dan Perilaku Komunikasi Digital. Warta ISKI, 2(01), pp.1-7.

ZAINAL, N., YAMADA, Y. AND KAMARUDIN, M., 2016. Low Sidelobe And Wideband Characteristics Of Density Tapered Arrays For 5g Mobile Systems. Jurnal Teknologi, 78(6-2). 